\title{
ASESMEN PERKEMBANGAN KOGNITIF ANAK USIA 5-6 TAHUN
}

\author{
Khadijah $^{1}$, Nurul Amelia ${ }^{2}$ \\ ${ }^{1,2}$ Universitas Islam Negeri Sumatera Utara \\ khadijah@uinsu.ac.id
}

\begin{abstract}
Cognitive development is the process of thinking of children and finding solutions to what is thought. Through the assessment of student performance and work activities as a basis for making educational decisions that are useful for students. The purpose of this study is to find out the material for developing cognitive abilities in children, describing the application of assessment techniques (assessment), and the results / impacts of cognitive assessment in RA Al-Hidayah Semanggi. Research methods. The instrument developed was an observation sheet in the form of: anecdotal record, checklist, time sampling and the use of technological tools to record interview data. The data will be collected through observation, interviews, questionnaires, and documentation and then analyzed qualitatively. Research results show the cognitive development of children in RA AL-HIDAYAH has developed as expected, marked by the ability of children to follow commands / instructions from their teacher such as starting able to follow the prayer movement, can count, children can write some vocabulary, want to read story books. The assessment has a positive influence on the achievement of the development of cognitive abilities, both for teachers, students, and parents who will be used as a reference for children's development to further prepare children for a higher level.
\end{abstract}

Keywords: Cognitive Development Assessment, RA Al-Hidayah Semanggi

\begin{abstract}
Abstrak
Perkembangan kognitif merupakan proses berfikir anak dan menemukan solusi dari apa yang dipikirkan. Melalui asesmen kegiatan kinerja dan karya siswa sebagai dasar pengambilan keputusan pendidikan anak yang berguna bagi siswa. Tujuan dari penelitian ini adalah mengetahui materi kegiatan dalam mengembangkan kemampuan kognitif anak, mendeskripsikan penerapan teknik asesmen (penilaian), dan hasil/dampak adanya asesmen perkembangan kognitif di RA Al-Hidayah Semanggi. Metode penelitian. adapun Instrumen yang dikembangkan adalah lembar observasi berupa format: anecdotal record, checklist, time sampling dan penggunaan alat teknologi untuk merekam data wawancara. Data tersebut akan dikumpulkan melalui observasi, wawancara, angket, dan dokumentasi untuk kemudian dianalisis secara kualitatif.. Hasil penlitian menunjukan perkembangan kognitif anak di RA AL-HIDAYAH sudah berkembang sesuai harapan, di tandai dengan kemampuan anak dalam mengikuti perintah/instruksi dari gurunya seperti mulai mampu mengikuti gerakan sholat, dapat berhitung, anak dapat menulis beberapa kosa kata, mau membaca buku cerita. Asesmen meiliki pengaruh positif dalam pencapaian perkembangan kemampuan kognitif, baik untuk guru, peserta didik, maupun orang tua yang akan dijadikan acuan untuk perkembangan anak untuk selanjutnya mempersiapkan anak kejenjang yang lebih tinggi.
\end{abstract}

Kata kunci: Asesmen Perkembangan Kognitif, RA Al-Hidayah Semanggi 


\section{PENDAHULUAN}

Perkembangan kemampuan kognitif anak usia dini yang telah ditetapkan dalam STPPA Permendikbud No. 137 tahun 2014. Aspek perkembangan kognitif dibagi menjadi 3, yaitu: pertama, menyelesaikan permasalahan dalam belajar yaitu, mengenal konsep sederhana dalam kehidupan sehari-hari, mengenal berdasarkan fungsi, mengetahui konsep banyak dan sedikit, menggunakan benda-benda sebagai permainan simbolik, mengkreasikan sesuatu sesuai dengan ide dari dirinya sendiri yang terkait dengan segala bentuk pemecahan masalah, gejala rasa ingin tahunya dalam mengamati benda, mengenal pola suatu kegiatan dan menyadari pentingnya waktu, memahami kedudukan/posisi di dalam keluarga, ruang, dan lingkungan sosial. Kedua, berfikir logis yaitu mengelompokan benda berdasarkan fungsi, bentuk, warna dan ukuran, mengenal dampak sebab-akibat yang terkait dengan dirinya, mengelompokan benda yang sejenis, atau yang sama atau yang berpasangan dengan 2 variasi, mengenal pola (misal, $\mathrm{AB}-\mathrm{AB}$ dan $\mathrm{ABC}-\mathrm{ABC}$ ) dan mengulanginya, dan mengurutkan benda berdasarkan 4 variasi baik ukuran maupun warna. Ketiga, berfikir simbolik yaitu mengenal konsep bilangan, mengenal berbagai aspek anak berjalan secara holistik, membilang benda dari satu sampai sepuluh, terjadinya hal ini tidak secara terpisah dan dipengaruhi oleh berbagai faktor internal dan eksternal. Faktor internal adalah semua aspek perkembangan pada anak, faktor eksternal contohnya yaitu, keluarga, guru, dan berbagai sumber belajar yang lainnya. Anak sejak lahir hingga sampai usia 6 tahun merupakan pondasi awal bagi pertumbuhan dan perkembangan anak untuk usia selanjutnya. Pada usia ini pertumbuhan fisik dan perkembangan mental anak berkembang dengan sangat maju. Sekalipun Tuhan telah memberikan potensi bawaan pada anak, lingkungan memberikan peranan besar dalam membentuk sikap anak, kepribadian dan pengembangan pembelajaran anak. Setiap anak yang terlahir di dunia Tuhan menganugerahkan mereka dengan potensi yang berbeda-beda, sifat yang unik, memiliki kelebihan, bakat dan minat sendiri-sendiri yang perlu distimulasi melalui proses pendidikan.

Anak yang berusia empat sampai lima tahun, bentuk pendidikan yang diberikan adalah pendidikan Taman Kanak-kanak yang merupakan pendidikan pada jalur pendidikan formal. Undang-Undang Nomor 20 Tahun 2003 tentang Sistem Pendidikan Nasional pasal 1 ayat 14 menyatakan bahwa "Pendidikan anak usia dini adalah suatu upaya pembinaan yang ditujukan kepada anak sejak lahir sampai dengan usia enam tahun yang dilakukan melalui pemberian rangsangan pendidikan untuk membantu pertumbuhan dan perkembangan jasmani dan rohani 
agar anak memiliki kesiapan dalam memasuki pendidikan lebih lanjut" (Pusat Kurikulum Direktorat Pendidikan Anak Usia Dini, 2007).

Asesmen berasal dari istilah bahasa Inggris, yaitu assesment, namun dalam bahasa Indonesia istilah assesment sudah ditetapkan menjadi bahasa baku yaitu asesmen. Asesmen adalah proses pengamatan, pencatatan, dan pendokumentasian aktivitas kinerja, hasil karya siswa, dan bagaimana ia melakukannya sebagai dasar pengambilan keputusan yang berguna bagi siswa dalam pendidikan anak selanjutnya. (Suyanto, 2005) Senada dengan pendapat di atas, E.Johnson sebagaimana dikutip (Nugraha, 2008) memandang bahwa penilaian adalah mengumpulkan, menyeleksi, dan mengartikan informasi dalam mengambil suatu keputusan. Dalam Permendikbud No. 146 Tahun 2014 dijelaskan bahwa penilaian adalah proses pengolahan informasi, pengumpulan kemampuan untuk mengukur tingkat pencapaian kegiatan proses belajar anak.

Beberapa pengertian diatas menurut (Fadlillah, 2017) mempunyai masing-masing arti yang sama dengan lainnya. Assesmen dimaksudkan untuk mencari lebih dalam berbagai informasi dari peserta didik dengan tujuan untuk mengetahui perkembangan dari peserta didik. Pendidikan anak usia dini dalam kaitannya dengan assesmen yaitu, sebagai penilaian prosedur yang telah diatur sedemikian rupa dipergunakan dalam hal mendapatkan informasi dalam aspek kinerja dan kemajuan di berbagai aspek perkembangan yang dapat dicapai peserta didik setelah mengikuti kegiatan pembiasaan dalam batas waktu tertentu. Penilaian merupakan proses pengambilan informasi yang di proses dalam menentukan sasaran pencapaian perkembangan anak dan pengambilan keputusan,ketepatan atau pengakuan, tentang keadaan atau kemampuan anak (Wahyudin dan Agustin, 2011). Dari beberapa pendapat diatas dapat kita tarik kesimpulannya bahwa asesmen atau penilaian dalam pendidikan anak usia dini berguna untuk mengetahui tingkat pencapaian perkembangan anak yang lebih melihat pada proses yang dilakukan, bukan hasil akhir yang didapatkan. Sebagaimana diungkapkan (Suyanto, 2005) bahwa asesmen atau penilaian tidak dilakukan akhir program di kelas atau di akhir tahun TK, melainkan dilakukan secara sistematis dan berkelanjutan sehingga kemajuan dalam proses belajar siswa dapat diketahui dengan optimal (Mulyasari, 2020).

Menurut Feeney assessment authentic yaitu pada saat kegiatan belajar anak asesmen yang dilakukan dalam setting kehidupan yang nyata dan dalam keadaan yang natural. Authentic assessment bisa digunakan dalam berbagai keadaan yang alami, contohnya pada saat anak belajar dan bermain. Authentic assessment dilakukan untuk mengukur kemajuan 
perkembangan anak dalam kematangan prilaku, tahapan persiapan dan keterampilan pemahaman mengenai suatu konsep yang ada pada anak. Berikut ini adalah beberapa teknik pencatatan dalam observasi (Feeney, 2006) (Padilah, 2019). Anecdotal Record atau catatan anekdot adalah deskripsi atau penggambaran secara tertulis dari perilaku anak. 2) Event sampling digunakan sebagai dari time sampling, misalnya ketika suatu perilaku cenderung terjadi dalam waktu yang tidak dapat diperkirakan dibandingkan terjadi dalam periode waktu yang dapat diperkirakan. 3) Running Record merupakan suatu metode yang dipakai untuk mencatat perilaku anak secara menyeluruh yang dinarasi dan sesuai urutan kejadian. 4) time sampling adalah untuk mencatat dan melihat seberapa sering frekuensi dari sebuah perilaku terjadi dalam periode waktu yang telah ditentukan. 5) Checklist adalah list mengenai daftar tingkah laku yang berurutan dan didalamnya tersusun sebuah sistem dari suatu kategori. 6) Penggunaan teknik dokumentasi ini meliputi kegiatan mengabadikan proses kegiatan belajar dan bermain pada anak dalam bentuk foto dan video, menggunakan audio/video tape untuk mendukung segala kegiatan (Sofia Hartati, p. 21)

Awal mula istilah cognitive berasal dari kata cognition yang kata dasarnya knowing, berarti mengetahui. Cognition dalam arti yang luas menurut Nasier, ialah perolehan, penataan, perbedaan dan penggunaan pengetahuan (Khadijah, 2016). Selanjutnya kognitif juga dapat diartikan dengan kemampuan berfikir, kecerdasan dalam proses belajar yaitu kemampuan untuk mempelajari keterampilan dan konsep baru, keterampilan untuk memahami apa yang telah terjadi di lingkungannya, serta keterampilan dalam menggunakan kemampuan dalam mengingat dan menyelesaikan persoalan-persoalan sederhana (Pudjiati, Masykouri, dan Al Zena, 2011).

Sejalan dengan yang dikemukakan oleh Istilah (Maslihah, 2005) bahwa kognitif itu sendiri dapat diartikan sebagai kemampuan untuk memahami sesuatu. Artinya mengerti menunjukkan kemampuan untuk menangkap sifat, arti, atau keterangan mengenai sesuatu serta mempunyai gambaran yang jelas terhadap hal tersebut. Perkembangan kognitif sendiri mengacu kepada kemampuan yang dimiliki seorang anak untuk memahami sesuatu (Maslihah, 2005). Sementara itu di dalam kamus besar bahasa Indonesia, kognitif diartikan sebagai sesuatu hal yang berhubungan dengan atau melibatkan kognisi berdasarkan kepada pengetahuan faktual yang empiris (Alwi, Hasan, dkk, 2002).

Sebagian besar psikologi terutama kognitivis (ahli psikologi kognitif) memiliki keyankinan bahwa proses perkembangan kognitif manusia mulai terjadi sejak anak baru lahir (Khoiruzzadi, 2020). Bekal dan modal utama perkembangan manusia, yakini kapasitas motor 
dan sensory yang ternyata pada batas tertentu juga dapat dipengaruhi oleh aktifitas ranah kognitif. Hubungan sel-sel otak terhadap perkembangan bayi baru dimulai setelah ia berusia lima bulan saat kemampuan sensorinya (seperti melihat dan mendengar) benar-benar mulai tampak. Menurut para ahli psikologi kognitif, dayaguna kapasitas kognitif sudah mulai berjalan sejak manusia mulai mendayagunakan kapasitas motor dan daya sensorinya. Tetapi cara dan intensitas daya penggunaan kapasitas ranah kognitif tersebut masih belum bisa dipastikan kebenarannya ungkap Jahja dalam (Khadijah, 2016). Dari uraian latar belakang diatas maka peneliti melakukan penelitian berjudul "Asesmen Pengembangan Kognitif dan Motorik Anak Usia 5-6 Tahun di RA Al-Hidayah Semanggi”.

\section{METODE PENELITIAN}

Metode yang digunakan dalam penelitian ini oleh peneliti adalah penelitian kualitatif. Menurut Taylor dan Bogdan metode penelitian kualitatif adalah salah satu prosedur penelitian yang menghasilkan data deskriptif berupa hasil wawancara maupun tulisan dan perilaku orang-orang yang diamati (Meleong, Lexy J, 2012) (Anggraini, 2019) (Kuswanto, 2016).

Menurut John W Creswell yang dikutip oleh hamid patiliam: "Penelitian kualitatif adalah proses penyelidikan untuk memahami masalah social berdasarkan pada penciptaan gambar holistic yang dibentuk dengan kata-kata melaporkan pandangan informan secara terperinci dan disusun dengan sebuah latar ilmiah" (Hamid Patiliam, 2013) (Pratiwi, 2015) (Purwanti, 2016).

Kegiatan penelitian dilakukan di RA Al- Hidayah Semanggi, yang beralamatkan di Jl. Binjai Km. 11,5 Perum. Semanggi Indah Blok C No. 7-8-9. Pemilihan RA Al- Hidayah Semanggi sebagai tempat penelitian berdasarkan pertimbangan, bahwa RA ini lokasinya lebih dekat dengan tempat tinggal peneliti. Adapun waktu penelitian ini dilaksanakan sejak tanggal 11 sampai 22 November 2019. Subjek pada penelitian ini adalah anak Kelompok B sebanyak 28 anak. Dan objek pada penelitian ini adalah perkembangan kognitif anak pada kelompok B di RA. Al-Hidayah Semanggi.

Teknik pengumpulan data dalam penelitian ini, teknik yang digunakan peneliti dalam memperoleh data-data tersebut adalah metode observasi/pengamatan langsung, wawancara dan dokumentasi. Metode observasi bertujuan untuk mengetahui deskripsi tentang perkembangan kognitif anak kelas B di RA. Al-Hidayah. Peneliti melakukan kegiatan observasi di dalam maupun di luar kelas dengan mengamati perilaku pada masing-massing anak. Dalam melaksanakan kegiatan pengamatan, peneliti menggunakan pedoman observasi 
untuk memperoleh data yang diinginkan dan setiap informasi yang ditemukan kemudian dicatat dalam bentuk catatan lapangan. Catatan lapangan digunakan peneliti untuk mencatat perkembangan kognitif sebagai bukti konkret untuk menganalisis data. Wawancara ditujukan kepada sumber data yang terlibat dalam perkembangan kognitif anak di Kelompok B. Teknik wawancara yang dilakukan dalam penelitian ini adalah wawancara terstruktur dengan menyiapkan instrumen penelitian berupa pertanyaan-pertanyaan tertulis. Sumber data dalam teknik wawancara adalah guru kelas, dan orangtua. Kegiatan wawancara dilakukan di RA. AlHidayah Semanggi dengan menggunakan pedoman wawancara yang disesuaikan dengan sumber dan peneliti. Wawancara tidak hanya dilakukan kepada guru, melainkan juga kepada orangtua murid guna mengetahui perkembangan kognitif anak pada usia 5-6 tahun di RA. AlHidayah. Dokumentasi yang digunakan dalam penelitian ini berupa foto aktivitas yang dilakukan anak ketika mereka mengerjakan kegiatan, video aktivitas anak ketika mengerjakan kegiatan, dan portofolio.

Data-data penilaian yang telah terkumpulkan dari berbagai sumber-sumber penelitian. Data instrument tersebut diolah dan di analisis secara sistematis sehingga mencapai hasil yang dapat dipertanggung jawabkan.

Peneliti menganalisis data dengan model (miles dan huberman, 2014. 19) selama peneliti berada dilapangan, aktivitas dalam analisis data meliputi data reduction, data display, dan conclusion drawing/verification. Tiga langkah proses analisa kualitatif tersebut dapat dijelaskan sebagai berikut:

1. Reduksi Data

Langkah awal dalam menganalisa adalah mereduksi data yaitu penulis menyimpulkan semua hasil wawancara, memilih hal yang paling utama, memfokuskan pada yang penting serta membuang hal yang tidak penting.

2. Penyajian Data

Setelah data direduksi , maka langkah selanjutnya adalah mendisplay data. Display data merupakan proses mendeskripsikan kumpulan informasi secara sistematis dalam bentuk susunan yang jelas untuk membatu penulis menganalisa hasil penelitian. Untuk memudahkan penyajian data ini peneliti membuat catatan lapangan dalam bentuk teks naratif untuk memudahkan penguasaan informasi atau data yang dimaksud.

3. Penarikan Kesimpulan

Penarikan kesimpulan merupakan kegiatan dengan maksud untuk menemukan makna diri, data yang telah disajikan, misalnya dengan menghubung-hubungkan antara satu 
dengan yang lain. Kesimpulan data dilakukan secara sementara, kemudian diverifikasikan dengan cara mencari data yang lebih mendalam dengan, mempelajari kembali hasil data yang telah terkumpul.

\section{HASIL PENELITIAN DAN PEMBAHASAN}

\section{A. Deskriptif Data}

Proses assesmen atau penilaian pada anak usia dini adalah melakukan pengamatan, pencatatan, dan dokumentasi karya serta seperti apa proses dalam menghasilkan suatu karya. Penilian tidak hanya digunakan untuk mengukur suatu keberhasilan karya tersebut tetapi untuk menilai dan mengetahui perkembangan atau kemajuan dari hasil belajar anak. Dengan melakukan penilaian individu dapat mengetahui minat, bakat, kelebihan, dan kelemahan anak. Tujuan dari asesmen ialah mengidentifikasi standar perkembangan anak, untuk mengetahui kendala-kendala apa saja yang terjadi pada anak, atau program pendidikan yang tepat bagi anak. Bowman menyebutkan 4 tujuan asesmen yaitu (a) assessment to support learning, asesmen dilakukan untuk mendukung pembelajaran (b) assessment to identify special need, penilaian dimaksudkan untuk mengidentifikasi kebutuhan khusus (c) assessment for program evaluation and monitoring trends, penilaian untuk evaluasi program dan pemantauan (d) assessment for program/school accountability, penilaian untuk akuntabilitas program/sekolah (Sitti R.Talango, pp. 51-52).

Penilaian berfungsi untuk memberikan feed back atau umpan balik kepada guru untuk memperbaiki kegiatan pembelajaran termasuk dalam berbagai kegiatan, memberikan bahan pertimbangan bagi guru untuk melakukan kegiatan terhadap anak agar fisik maupun psikisnya dapat tumbuh dan berkembang secara optimal, memberikan informasi kepada orangtua tentang tingkat pencapaian perkembangan, memperbaiki, meningkatkan bimbingan dan motivasi serta sebagai bentuk penanggung jawaban lembaga, memberikan informasi kepada orangtua dalam melakukan pendidikan keluarga yang sesuai dan terpadu dengan proses pembelajaran di PAUD, sebagai bahan pertimbangan dalam melakukan kegiatan bimbingan terhadap anak agar perekembangan mereka dapat berjalan secara optimal, mengetahui tingkat perkembangan fisik dan mental anak, mengetahui hambtan-hambatan dan kesulitan yang dialami anak dalam kegiatan belajar-mengajar, menilai tingkat pengetahuan dan keterampilan anak, memberikan bahan masukan bagi berbagai pihak dalam rangka pembinaan selanjutnya 
terhadap anak, khususnya pada jenjang pendidikan berikutnya, dan sebagai sumber data atau masukan bagi kegiatan belajar-mengajar selanjutnya.( Dirman dan Juarsuh, 2014: 224)

Berdasarkan Permen No. 137 Tahun 2014 Tentang Standar Pendidikan Anak Usia Dini Pasal VI Bab 19 menjelaskan adanya beberapa prinsip penilaian dalam pembelajaran anak usia dini yaitu : 1) Edukatif, prinsip edukatif yaitu mendorong anak menuju perkembangan yang optimal, 2) Otentik, prinsip otentik berarti bahwa penilaian bertujuan pada proses belajar yang berkelanjutan/berkesinambungan dan hasil belajar yang mencerminkan kemampuan anak saat belajar, 3) Objektif, penilaian harus didasarkan pada indikator perkembangan anak serta bebas dari pengaruh, 4) Akuntabel, pelaksanaan penilaian harus sesuai prosedur dan kriteria yang jelas, serta ditetapkan pada awal pembelajaran, 5)Transparan, penilaian prosedur dan hasil yang dapat diakses oleh semua pihak pemangku kepentingan.

Menurut (Khadijah, 2016) pengembangan perkembangan kognitif meliputi:

1. Pengembangan auditori anak usia dini.

2. Pengembangan sains permulaan

3. Pengemangan geometri anak usia dini.

4. Pengembangan aritmatika anak usia dini

5. Pengembangan visual anak usia dini.

6. Pengembangan taktil anak usia dini.

7. Pengembangan kinestetik anak usia dini.

Penilaian perkembangan kognitif anak usia dini digunakan untuk:

1. Mengetahui berbagai aspek perkembangan anak secara individual.

2. Mengidentifikasi dan memperbaiki masalah perkembangan pada anak.

3. Membuat perencanaan program dan memberikan respons balik bagi anak.

4. Memberikan tempat dan program yang tepat bagi anak.

5. Mendiagnosa adanya hambatan perkembangan maupun identifikasi penyebab masalah belajar anak.

Dengan demikian proses penilaian yang dilakukan hendaknya disesuaikan dengan tujuan penilaian yang akan dicapai, agar mendapatkan hasil yang maksimal.

1. Deskripsi Assesmen Perkembangan Kognitif Anak

Berdasarkan hasil observasi yang dilakukan di RA. Al-Hidayah Semanggi, bahwa proses belajar mengajar dimulai pada pukul 07.00-11.00 WIB. Sebelum anak-anak datang, 
guru mempersiapkan semua alat, bahan, dan media yang akan digunakan sesuai dengan kegiatan pembelajaran dalam RKH. Sebelum memulai kegiatan pembelajaran di dalam kelas, anak melakukan kegiatan yang bersifat fisik atau motorik kasar seperti berbaris atau senam yang dilakukan secara menyenangkan agar anak menjadi lebih siap dan berkonsentrasi ketika kegiatan pembelajaran berlangsung.

Adapun assesmen yang dilakukan berkaitan dengan materi keterampilan kognitif (ketika diberi instruksi) seperti a) Sangat sedikit kesulitan mengikuti instruksi, b) Agak kesulitan tetapi tidak membutuhkan bantuan, c) Kesulitan dalam mengikuti instruksi dan membutuhkan bantuan d) Kesulitan dan tidak menyelesaikan tugas sekalipun dibantu.

Berdasarkan observasi yang dilakukan peneliti di RA. Al-Hidayah Semanggi, peneliti melakukan asesmen Keterampilan kognitif (ketika diberi instruksi) anak di RA. Al-Hidayah dengan melakukan beberapa kegiatan diantaranya yaitu melaksanakan Shalat Dhuhah, kegiatan membaca dan menulis, berhitung, mewarnai dasar, membedakan sikap benda serta meniru

\section{a. Kegiatan Shalat}

Di RA. Al-Hidayah Semanggi, kegiatan shalat dhuha merupakan kegiatan yang sangat rutin. Anak-anak melakukan shalat dari hari senin- hari jumat yang dimulai pada pukul 09.00 wib. s/d selesai. Kegiatan shalat merupakan salah satu cara guru-guru di RA. Al-Hidayah dalam mengembangkan kognitif pada anak. Hal ini dikarenakan bacaanbacaan shalat beserta gerakannya di ulangi setiap harinya sehingga anak dapat mengingat bacaan beserta gerakannya. Selain itu pelajaran shalat merupakan amalan yang harus ditirukan persis seperti yang diajarkan. Oleh karena itu setiap anak yang bisa mengikuti gerakan dan membacakan bacaan shalat, itu artinya anak tersebut mampu mempelajari sesuatu tanpa disertai imajinasinya, selain itu anak juga sudah mampu menirukan sesuatu tanpa tercampur dengan hayalannya.

Berdasarkan wawancara yang dilakukan dengan guru kelas, bahwa anak-anak di kelas B ini juga perkembangan kognitifnya juga berkembang sesuai dengan harapan, dari kegiatan shalat yang dilakukan, anak-anak lebih cepat hapal dengan bacaan dan gerakannya, dan guru kelas juga mengatakan bahwa setiap pengulangan adalah cara untuk memperkuat ingatan anak-anak.

b. Kegiatan Membaca dan Menulis

Berdasarkan observasi yang dilakukan, peneliti dapat menyimpulkan bahwa dalam mengembangkan kognitif anak di RA. Al-Hidayah ini, tidak hanya melalui kegiatan 
shalat melainkan juga melalui kegiatan membaca dan menulis. Pembelajran membaca dan menulis adalah pembelajaran yang wajib setiap harinya. Berdasarkan wawancara dengan wali kelas B, bahwa 9 anak dari 12 anak di kelas B rata-rata sudah dapat mengenal huruf bahkan dikte, menggabungkan beberapa kosa kata dan bahkan sudah ada yang pandai membaca. Hal ini termasuk perkembangan yang cepat dilihat dari waktu ini masih semester ganjil. Anak sdah mampu menyimak dan menceritakan kembali dongeng yang yang dibawakan guru.

“Anak-anak suka sekali mendengar dongeng, dan setelah guru selesai bercerita, mereka suka Berebut boneka tangan untuk menceritakan kembali dongeng yang baru disampaikan guru tadi kepada temannya. Anak sudah mampu menyebutkan judul lagu. Seperti saat peneliti turun ke lapangan, guru menyanyikan lagu "macam-macam profesi”. "Kalau urusan lagu, anak-anak sangat mudah menghafal. Sampai-sampai lagu yang didengar dari youtube atau TV di rumahnya sering dinyanyikan di sekolah".

c. Memahami perintah

"Anak sudah mampu memahami perintah guru. Seperti saat guru meminta anak mengeluarkn bekal makanan dari tasnya, lalu meletakkan di atas meja, dan saat guru meminta anak membuang sampah, anak berebut juga mengejar tong sampah”. Anak sudah mampu mendengar dan membedakan bunyi“Anak-anak ini sudah bisa mendengarkan bunyi, seperti bunyi motor dan mobil, bunyi hujan dan air kran, bahkan mempraktekkannya. Seperti saat guru meminta anak bunyikan suara gendang, anak akan meokok meja secara bersamaan (menokok meja menyerupai gendang) begitu juga jika diminta anak membunyika gitar, maka anak akan menaruh posisi tangannya layaknya orang yang sedang bermain gitar sambil berucap "jreng-jreng”.

d. Berhitung

Begitu juga dengan pengenalan angka tidak jauh beda dengan perkembangan pengenalan huruf. Berdasarkan hasil wawancara dengan guru kelas B bahwa mengajarkan berhitung pada anak-anak tidaklah mudah, guru-guru harus memulai pembelajaran dari mulai pengenalan angka sampai mengehitung dari yang sederhana seperti menghitung jari sendiri, menghitung gambar pada majalah dan kemudian beralih ke penjumlahan angka. Hal yang paling utama dalam mengajarkan tentang penjumlahan ini yaitu dengan mengenalkan symbol tanda penjumlahan dan tanda pengurangan. Dan Alhamdulilah anak-anak di kelas B sudah dapat mengenal kedu tanda gtersebut, ucap wali kelas B. wali kelas juga mengatakan hampir $70 \%$ anak-anak dikelas B sudah dapat 
berhitung secara sederhana. Ini artinya perkembangan kognitif mereka berkembang dengan baik. Anak sudah mampu membedakan kecil dan besar, seperti mengelompokkan bola kecil dan besar. Anak juga sudah mampu membedakan mana tinggi dan rendah, ukuran panjang dan pendek, jauh dan dekat. Anak sudah mampu mengurutkan angka 120, anak juga sudah mampu mengurutkan benda 1-10 berdasarkan bentuk.

e. Membedakan sifat benda

Anak belum terbiasa membedakan mana padat panas cair, namun sudah mampu membedakan mana panas dan dingin, tebal dan tipis, Anak mampu menyusun lego menjadi istana“Biasanya anak-anak bermain bersama dalam pembuatan istana, bermacam-macam bentuk istana yang mereka buat"

f. Mewarnai dasar

Anak sudah mampu mewarnai gambar yang diberikan guru "anak mengerti instruksi dari gurunya. Sebagai contoh, jika guru menganjurkan warna pisang itu kuning, maka rata-rata anak memilih warna kuring"

g. Meniru

"Anak sudah mampu menirukan suara hewan, yaitu suara kucing, ayam, bebek, sapi, dan kambing. Anak anak sangat suka jika guru meminta mereka memperagakan suara-suara ini denga baik. Selain itu, anak juga sudah mampu menirukan bentuk segi tiga, segi empt dan lingkaran yang ditulis guru di papan tulis"

Tabel 3. Hasil Penelitian Perkembangan Kognitif AUD

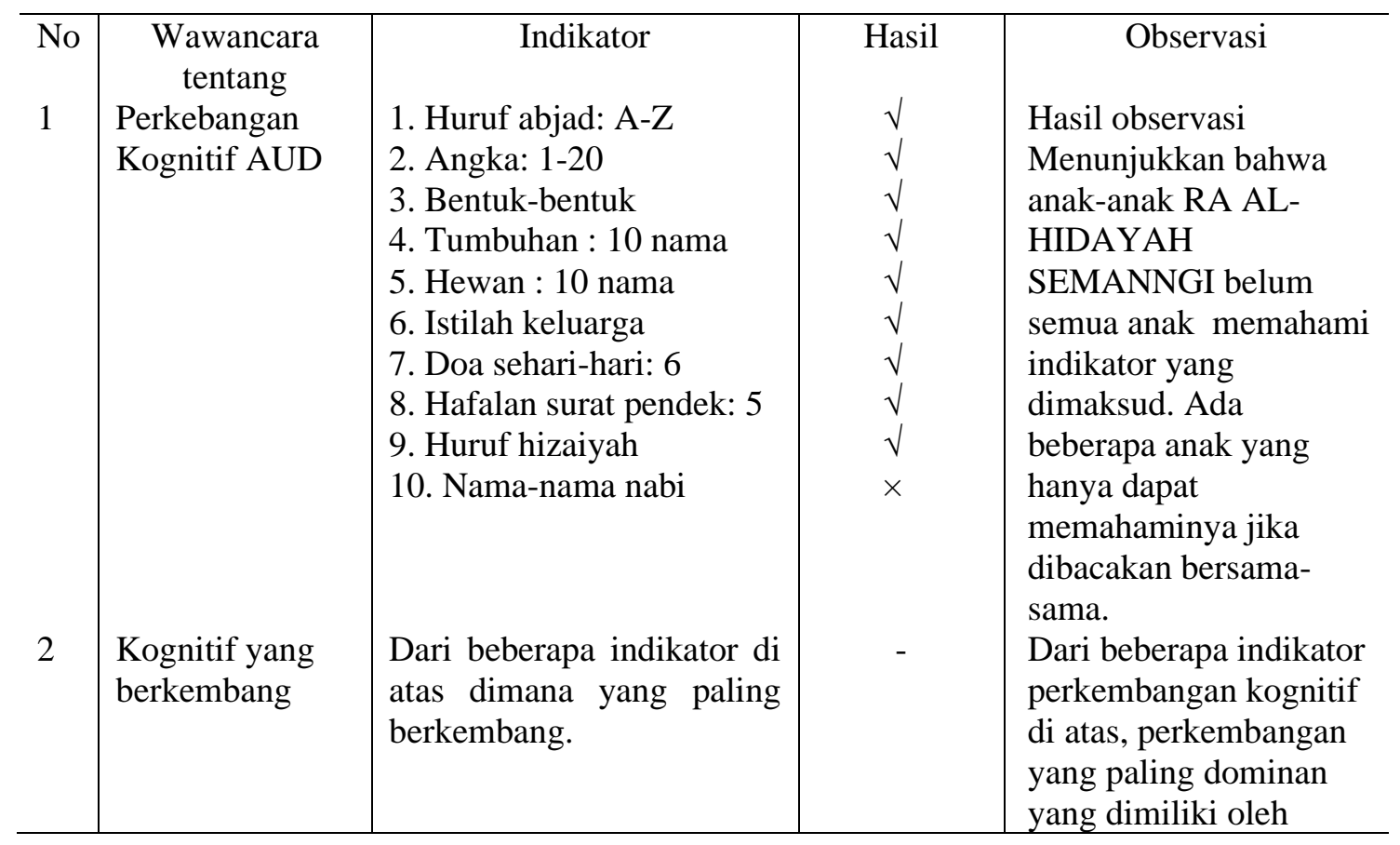




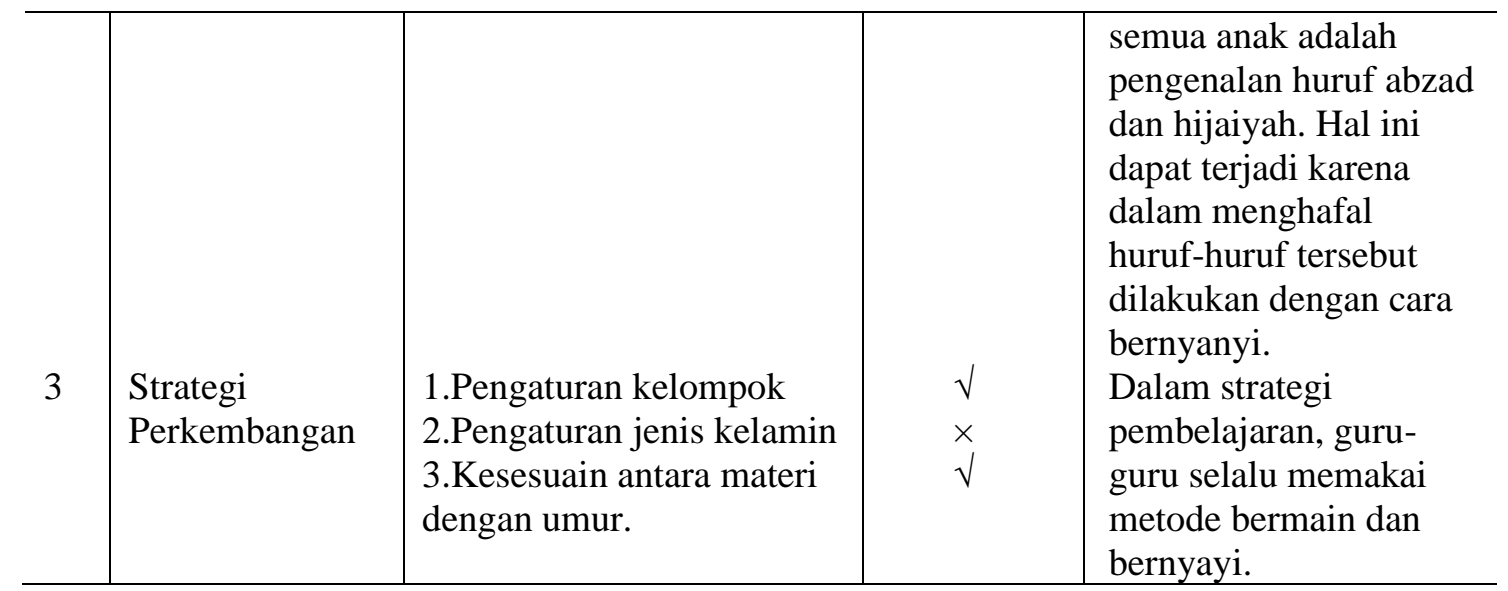

\section{KESIMPULAN dan SARAN}

Asesmen yaitu suatu proses pengamatan, pencatatan, dan pendokumentasian semua aktivitas kinerja dan karya siswa dan bagaiman ia melakukannya sebagai dasar pengambilan keputusan pendidikan anak yang berguna bagi siswa. Sejalan dengan itu, E Johnson sebagaimana memandang bahwa penilaian merupakan suatu proses memilih, mengumpulkan, dan mengartikan informasi untuk membuat keputusan. Komponen-komponen asesmen pada anak usia dini salah satunya adalah perkembangan kognitif membedakan dan menggabungkan melaksanakan Shalat Dhuhah, kegiatan membaca dan menulis, berhitung, mewarnai dasar, membedakan sikap benda serta meniru

Berdasarkan analisis data-data dari observasi dan wawancaraa secara keseluruhan dapat dilihat bahwa tingkat pencapaian perkembangan kognitif anak kelompok B di RA. AlHidayah Semanggi dari 12 anak pada usia 5-6 tahun pada perkembangan kognitifnya berkembang sesuai dengan harapan. Hal ini bisa dilihat dari kegiatan mereka sehar-hari. dalam mengembangkan kognitif anak di RA. Al-Hidayah lebih sering menggunakan kegiatan seperti Shalat, Menulis, Membaca, dan Menulis dan keseluruhan kegiatan dapat dilihat anak sudah mampu mengikuti instruksi yang diberikan guru.

\section{DAFTAR PUSTAKA}

Anggraini, W., \& Kuswanto, C. W. (2019). Teknik Ceklist Sebagai Asesmen Perkembangan Sosial Emosional di RA. Al-Athfaal: Jurnal Ilmiah Pendidikan Anak Usia Dini, 2(2), 61-70. https://doi.org/10.24042/ajipaud.v2i2.5248

Dirman dan juarsuh. (2014). Penilaian dan Evaluasi Dalam rangka Implementasi Standar Proses Pendidikan Siswa, Jakarta: Rineka Cipta.

Fadlillah, M. (2017). Bermain \& Permainan Anak Usia Dini. Jakarta: Kencana. 
Hamid Patiliam. (2013). Metode Penelitian Kualitatif, Bandung Alpa Beta.

Hartati, S. (2017). Pengembangan Model Asesmen Perkembangan Anak Taman KanakKanak Di DKI Jakarta. Jurnal Pendidikan Usia Dini,11(1), 1930.DOI: https://doi.org/10.21009/JPUD.111.02

Khadijah. (2016). Pengembangan Kognitif Anak Usia Dini, Medan: Perdana Publishing.

Khoiruzzadi, Muhammad, dkk. (2020). Upaya Guru dalam Memaksimalkan Perkembangan Kognitif, Sosial dan Motorik Anak Usia Dini. JECED. Vol. 2. No. 1. https://doi.org/10.15642/jeced.v2i1.561.

Kuswanto, C. W. (2016). Penyusunan tes fisik atlet pencak silat dewasa kategori tanding. Jurnal Keolahragaan, 4(2), $145-154$. DOI: https://doi.org/10.21831/jk.v4i2.6423

Meleong, Lexy J. (2012). Metode Penelitian Kualitatif, Bandung: Remaja Rosdakarya, 2012. Mena, \& Eyer. (2009). Infants, toddlers, and caregivers. New York, NY: McGraw-Hill. Mulyasari, dkk. (2020). Peningkatan Keterampilan Sosial Melalui Kegiatan Tari Saman. Jurnal Obsesi: Jurnal Pendidikan Anak Usia Dini. Vo. 4 No. 2. https://doi.org/10.31004/obsesi.v4i1.240

Nasional, P. K. P. (2007). Kerangka dasar kurikulum pendidikan anak usia dini. Jakarta: Derpartemen pendidikan nasional.

Nugraha, Ali dkk. (2005). Kurikulum dan Bahan Belajara TK. Jakarta: Universitas Terbuka.

Padilah dan Novianti. (2019). Implementasi Kegiatan Bermain Papercraft dalam Meningkatkan Kemampuan Motorik Halus Anak Kelas B PAUD Taman Sari Banyuasin. PAUD Lectura: Jurnal Pendidikan Anak Usia Dini. VOL. 3. No. 1. https://doi.org/10.31849/paud-lectura.v3i01.3273

Pratiwi, D. D. (2015). Analisis kemampuan komunikasi matematis dalam pemecahan masalah matematika sesuai dengan gaya kognitif dan gender. Al-Jabar: Jurnal Pendidikan Matematika, 6(2), 131-142. https://doi.org/10.24042/ajpm.v6i2.28

Purwanti, R. D., Pratiwi, D. D., \& Rinaldi, A. (2016). Pengaruh Pembelajaran Berbatuan Geogebra terhadap Pemahaman Konsep Matematis ditinjau dari Gaya Kognitif. AlJabar: Jurnal Pendidikan Matematika, 7(1), 115-122. https://doi.org/10.24042/ajpm.v7i1.131

RI, M. (2014). Permendikbud RI No 137 tahun 2014. Jakarta: Mendikbud RI. 
Sitti R.Talango. (2018). “Assesmen Perkembangan Anak (Studi Kasus Assesmen Perkembangan Anak Usia 2 Tahun)”. Jurnal Tadbir:Jurnal Manajemen Pendidikan Islam, Volume 6 Nomor 2 Tahun.

Sum, Theresia Alviani dan Emilia Greceila Mega Taran. 2020. Kompetensi Pedagogik Guru PAUD dalam Perencanaan dan Pelaksanaan Pembelajaran. Jurnal Obsesi: Jurnal Pendidikan Anak Usia Dini. Vo. 4 No. 2. https://doi.org/10.31004/obsesi.v4i2.287

Suyadi. (2016). Perencanaan dan asesmen Perkembangan pada Anak Usia Dini (Studi Kasus pada Lembaga PAUD di Daerah Istimewa Yogyakarta). Golden Age: Jurnal Ilmiah Tumbuh Kembang Anak Usia Dini, 1(1), 65-83.

Suyanto, Slamet. (2005). Konsep dasar Pendidikan Anak Usia Dini. Jakarta: Dirjen Dikti Depdiknas.

Zahroh, Amilatul dkk. 2019. Peningkatan Keterampilan Motorik Kasar Melalui Alat Permainan Simpai pada Anak Kelompok A di Taman Kanak-Kanak Dharma Wanita Bangun Ungging Mojokerto. JECED. Vol 1. No. 1. https://doi.org/10.15642/jeced.v1i1.493. 